\title{
PENGOLAHAN LABU KUNING MENJADI BERBAGAI PRODUK OLAHAN PANGAN
}

\author{
Tanwirul Millati1), Udiantoro'), Raihani Wahdah²) \\ 1)Program Studi Teknologi Industri Pertanian, Fakultas Pertanian, Universitas Lambung Mangkurat, Banjarmasin, \\ Kalimantan Selatan, Indonesia \\ 2)Program Studi Agronomi, Fakultas Pertanian, Universitas Lambung Mangkurat, Banjarmasin, Kalimantan Selatan, Indonesia \\ Corresponding author : Tanwirul Millati \\ E-mail : t_millati@ulm.ac.id
}

Diterima 16 September 2020, Direvisi 05 Oktober 2020, Diterima 06 Oktober 2020

\begin{abstract}
ABSTRAK
Kecamatan Daha Selatan kabupaten Hulu Sungai Selatan Kalimantan Selatan merupakan daerah penghasil labu kuning. Selama ini labu kuning hanya dimanfaatkan untuk campuran sayuran dan kue tradisional, seperti nagasari. Untuk meningkatkan nilai tambah dan penganekaragaman pangan lokal berbasis labu kuning dilakukan pelatihan mengenai pengolahan labu kuning. Pengolahan labu kuning dibagi menjadi dua tahap, yaitu pengolahan labu kuning menjadi tepung dan pengolahan tepung labu kuning menjadi cake, kue kering, dodol dan kerupuk. Tujuan dari kegiatan ini adalah memberi ketrampilan dan pengetahuan pengolahan labu kuning kepada masyarakat dengan harapan dapat dikembangkan sebagai sumber ekonomi keluarga. Kegiatan ini diikuti oleh 22 peserta yang mewakili lima desa yang ada di kecamatan Daha Selatan. Hasil kegiatan menunjukkan bahwa masyarakat sangat antusias untuk mengolah labu kuning menjadi beberapa produk olahan karena selain warna produknya menarik (kuning), rasanya enak dan produk olahan bermacam-macam. Produk olahan labu kuning oleh peserta akan diikutkan dalam pameran pembangunan yang diadakan di tingkat provinsi.
\end{abstract}

Kata Kunci: labu kuning; nilai tambah; pangan lokal; penganekaragaman pangan; produk olahan pangan.

\begin{abstract}
Daha Selatan, Hulu Sungai Selatan District, South Borneo is a sub district which produce pumpkin. Thus far, pumpkin is only used as vegetable mixture and traditional cake, such as Nagasari. The added value and diversification of pumpkin-based products can be increased by training in pumpkin processing. There is two step of pumpkin processing. First step is to processed pumpkin into flour and then the flour could be used to made food products such as, cake, cookies, dodol and crackers. The purpose of this activity is to provide the community with skills and knowledge in processing pumpkin with the expectation it can be developed as a source of family economy. This activity was attended by 22 representatives from five villages in Daha Selatan. The result of this activity show the community processed pumpkin with enthusiasm into various products because it has appealing color (yellow) and tastes good, beside that the products could be has more variance. Pumpkin product processed by participant would be included in development exhibition held at the provincial level.
\end{abstract}

Keywords: pumpkin; added value, local food; food diversification; food products.

\section{PENDAHULUAN}

Banyak bahan pangan lokal Indonesia yang mempunyai potensi gizi dan komponen bioaktif yang baik, namun belum dimanfaatkan secara optimal. Salah satu penyebabnya adalah keterbatasan pengetahuan masyarakat akan manfaat komoditas pangan tersebut, baik dari aspek gizi maupun aspek kesehatan. Labu kuning (Cucurbita moschata) termasuk dalam komoditas pangan lokal yang pemanfaatannya masih sangat terbatas.

Selain mengandung karbohidrat, labu kuning juga kaya akan kandungan vitamin, terutama vitamin A dan C yang merupakan antioksidan yang bermanfaat untuk kesehatan. Labu kuning merupakan bahan pangan yang kaya serat pangan terutama pektin, senyawa bioaktif, $\beta$-karoten, vitamin A, tocopherol, vitamin lain termasuk $\mathrm{B} 6, \mathrm{~K}, \mathrm{C}$, thiamine, dan riboflavin, serta beberapa jenis mineral $(K, P$, $\mathrm{Mg}, \mathrm{Fe}$ dan $\mathrm{Se}$ ). Kandungan serat pangan yang tinggi dalam bentuk pektin dapat mengontrol level serum insulin, menurunkan tingkat gula darah, meningkatkan toleransi glukosa dan memberikan proteksi terhadap berbagai penyakit seperti diabetes, penyakit 
kardiovaskular, konstipasi serta kanker usus besar (Adams et al., 2011).

Hasil penelitian Carvalho et al. (2012) menunjukkan bahwa labu kuning memiliki total karotenoid 234,21-404,98 $\mu \mathrm{g} / \mathrm{g}$, a-karoten 67,06-72,99 $\mu \mathrm{g} / \mathrm{g}$, dan $\beta$-karoten 244,22-141,95 $\mu \mathrm{g} / \mathrm{g}$. $\beta$-karoten merupakan antioksidan yang dapat digunakan sebagai penangkal berbagai jenis kanker dan serangan jantung, Air buahnya berguna sebagai penawar racun binatang berbisa, dan bijinya dapat digunakan untuk obat cacing pita dan memainkan peranan penting dalam mencegah penyakit degeneratif seperti diabetes mellitus (kencing manis), arterosklerosis (penyempitan pembuluh darah), jantung koroner, tekanan darah tinggi, bahkan bisa pula mencegah kanker (Hassan, 2014). Manfaat lain labu kuning adalah mengobati demam, migran, diare, penyakit ginjal serta membantu menyembuhkan radang.

Warna kuning daging buahnya pertanda kandungan karotenoidnya ( $\beta$-karoten) sangat tinggi. Kandungan $\beta$-karoten yang terdapat dalam labu kuning dapat menggantikan penggunaan pewarna dalam pengolahan pangan, terutama warna kuning.

Berdasarkan kandungan gizi dan manfaat kesehatan, labu kuning merupakan pangan lokal yang sangat potensial untuk dikembangkan sebagai alternatif bahan baku atau substitusi baku pada berbagai produk olahan pangan. Oleh karena itu untuk meningkatkan nilai tambah labu kuning dan mendukung upaya pemerintah dalam penganekaragaman pangan dapat dilakukan dengan mengolah buah labu kuning menjadi berbagai macam produk olahan pangan.

Labu kuning tidak mudah rusak karena mempunyai kulit tebal dan keras sehingga dapat bertindak sebagai penghalang laju respirasi. Hal inilah yang menyebabkan labu kuning relatif awet dibanding buah-buahan lainnya. Daya awet labu kuning dapat mencapai enam bulan atau lebih, tergantung pada cara penyimpanannya. Meskipun labu kuning mempunyai daya simpan lama, tetapi penyimpanan dalam bentuk bentuk buah segar kurang efisien karena memerlukan tempat yang luas dan kurang praktis dalam pemanfaatannya. Untuk mengatasi hal ini dapat dilakukan dengan mengolah labu kuning menjadi tepung, Tepung merupakan produk setengah jadi yang dianjurkan dalam penanganan pascapanen labu kuning karena lebih tahan disimpan, mudah dicampur (dibuat komposit), mudah dibentuk, dapat diperkaya dengan zat gizi, dan lebih mudah dalam pemanfaatannya sesuai dengan tuntutan kehidupan modern yang serba praktis. Rendemen yang dihasilkan pada pengolahan tepung labu kuning dengan perlakuan perendaman natrium metabisulfit sebesar 7,38$11,13 \%$ (Reza et al., 2019). Hasil penelitian Trisnawati et al. (2014) menunjukkan bahwa pengolahan tepung labu kuning dengan metode pengeringan oven microwave menghasilkan tepung dengan kadar air sebesar $7.64 \%$, kadar abu $5.31 \%$, kadar protein $5.19 \%$, kadar lemak $1.03 \%$, dan kadar karbohidrat $80.81 \%$, serat pangan tidak larut $10.21 \%$, serat pangan larut $5.00 \%$, total serat pangan sebesar $15.22 \%$, $\beta$ karoten $67.83 \mathrm{mg} / 100 \mathrm{~g}$, kapasitas antioksidan $184.40 \mathrm{ppm}$.

Hasil-hasil penelitian tentang pemanfaatan labu kuning menunjukkan bahwa labu kuning dapat digunakan untuk berbagai produk olahan pangan, baik secara langsung dari buah segar atau tidak langsung dengan diolah menjadi tepung terlebih dulu. Hasil penelitian Millati et al. (2006) menunjukkan bahwa tepung labu kuning dapat digunakan untuk subtitusi tepung ketan pada produk dodol sebesar $40 \%$, tepung tapioka pada kerupuk sebesar $30 \%$, tepung terigu untuk bolu sebesar $45 \%$ dan cookies sebesar $60 \%$. Sedangkan pada brownies kukus dapat menggantikan tepung terigu sebesar 30\% (Wulandari et al., 2019). Dalam bentuk pasta labu kuning, dapat digunakan untuk subtitusi terigu pada pengolahan mi kering sebesar $30 \%$ dari total bahan (Safriani et al., 2015) dan pada dodol untuk subtitusi tepung ketan sebesar $40-45 \%$ (Saroinsong et al., 2015).

Tujuan dari kegiatan ini adalah memberi keterampilan dan pengetahuan pengolahan labu kuning kepada masyarakat dengan harapan dapat dikembangkan sebagai sumber ekonomi keluarga

\section{METODE}

Kegiatan pengabdian ini dilaksanakan di Kecamatan Daha Selatan, Kabupaten Hulu Sungai Selatan, Kalimantan Selatan. Peserta kegiatan ini adalah perwakilan dari kelompok wanita tani yang berasal dari empat desa yang ada di kecamatan Daha Selatan. Metode yang dilakukan dalam kegiatan pengabdian ini terbagi menjadi dua tahap yang dilakukan selama satu hari.

Kegiatan tahap pertama berupa penyuluhan tentang nilai gizi dan manfaat labu kuning untuk kesehatan, pengolahan tepung labu kuning dan pemanfaatan tepung labu kuning sebagai substitusi bahan baku pada pengolahan dodol, bolu/cake, cookies dan kerupuk. Kegiatan tahap kedua adalah pelatihan pengolahan dodol, bolu, cookies dan kerupuk yang bahan bakunya disubtitusi dengan tepung labu kuning. 
Bahan yang digunakan meliputi tepung labu kuning, tepung ketan untuk produk dodol, tepung terigu untuk bolu dan cookies, tepung tapioka untuk kerupuk, gula pasir, margarin, pengembang, pelembut, vanili, bawang merah, bawang putih, garam dan ketumbar. Sedangkan alat yang digunakan antara lain mesin penepung, pengiris labu kuning, loyang, oven, mixer, blender, baskom berbagai ukuran, nyiru/ tikar untuk menjemur irisan labu kuning.

Pada akhir pelatihan dilakukan evaluasi dengan cara wawancara kepada para peserta mengenai materi sosialisai dan hasil pelatihan, terutama terhadap produk olahan labu kuning.

\section{HASIL DAN PEMBAHASAN \\ Kegiatan Penyuluhan}

Kegiatan penyuluhan dihadiri oleh 22 orang peserta yang berasal lima desa di kecamatan Daha Selatan, seperti terlihat pada Gambar 1. Setelah mengikuti kegiatan, peserta diharapkan dapat sebagai penggerak dalam melakukan pengolahan labu kuning di desa asalnya. Acara penyuluhan dibuka oleh Camat Daha Selatan dan dihadiri oleh pembakal, tokoh masyarakat dan seluruh peserta.

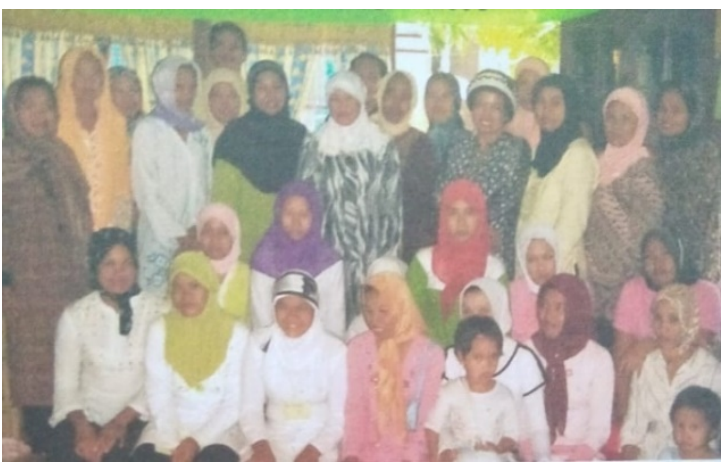

Gambar 1. Peserta penyuluhan

\section{Kegiatan Pelatihan}

Kegiatan pelatihan dilakukan untuk mempraktikan secara langsung teori yang sudah disampaikan pada tahap penyuluhan. Kegiatan ini dilakukan oleh peserta dengan didampingi oleh Tim kegiatan Pengabdian kepada Masyarakat Fakultas Pertanian Universitas Lambung Mangkurat. Suasana kegiatan pelatihan pengolahan tepung labu kuning menjadi berbagai poduk olahan pangan dapat dilihat pada Gambar 2.

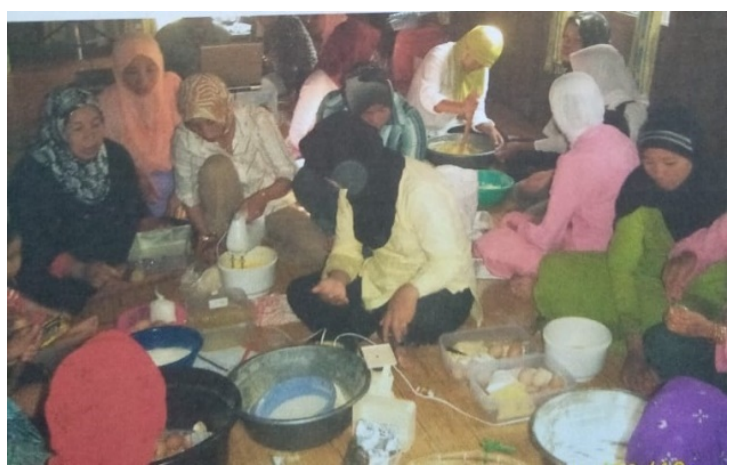

Gambar 2. Suasana kegiatan pelatihan

Tahapan kegiatan pelatihan yang dilakukan, yaitu:

1). Pembuatan chip labu kuning, dimulai dengan pengupasan dan pengirisan daging labu kuning dengan ketebalan 2-3 mm (lihat Gambar 3), selanjutnya dlakukan penyusunan irisan dalam nyiru/ tikar dan dilakukan pengeringan irisan labu kuning dengan cara penjemuran. Oleh karena pengeringan labu kuning memerlukan waktu 2-3 hari (tergantung cuaca), maka untuk kegiatan pelatihan sudah disiapkan chip/ irisan labu kuning yang telah kering.

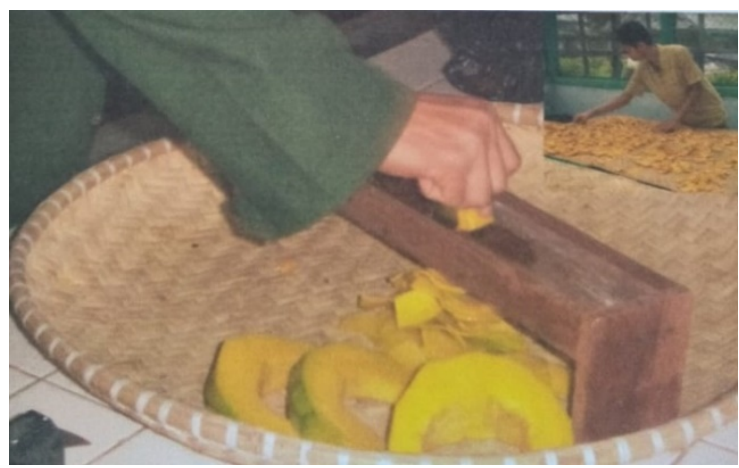

Gambar 3. Pengirisan dan penjemuran labu kuning

2). Pembuatan tepung, chip labu kuning yang sudah disiapkan sebelumnya, digiling dengan menggunakan mesin penepung yang sudah disiapkan, dan selanjutnya dilakukan pengayakan dengan ayakan 50 mesh untuk mendapatkan tepung labu kuning dengan ukuran yang lebih seragam. Tepung yang dihasilkan berwarna kuning tua dan rasanya sedikit manis, karena adanya kandungan gula dalam labu kuning. Pada Gambar 4 dapat dilihat mesin penepung, chip dan tepung labu kuning hasil penepungan. 


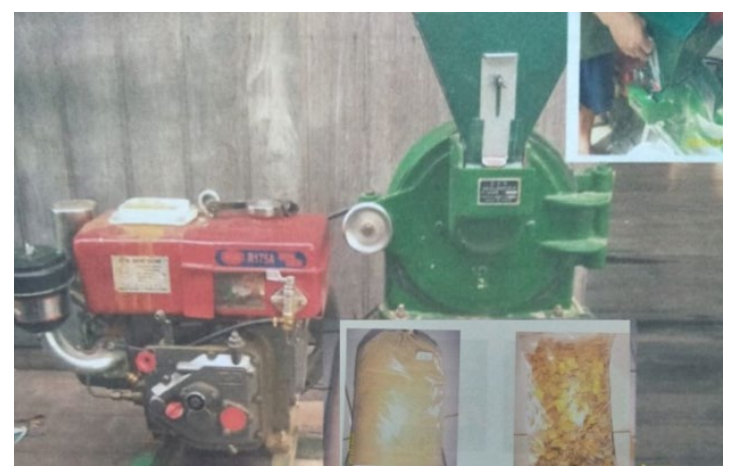

Gambar 4. Mesin penepung, chip dan tepung labu kuning

3). Pengolahan bolu/ cake, cookies, dodol, dan kerupuk. Sebelumnya peserta dibagi menjadi 4 kelompok dan setiap kelompok membuat satu produk olahan tepung labu kuning. Substtusi tepung labu kuning untuk setiap produk olahan jumlahnya berbeda, Untuk bolu dan cookies yang pada umumnya menggunakan tepung terigu sebagai bahan baku, disubstitusi tepung labu kuning sebesar $45 \%$ dan $60 \%$, sedang dodol yang bahan bakunya tepung ketan, disubstusi sebesar $40 \%$ dan kerupuk yang bahan bakunya tepung tapioka sebesar $30 \%$. Produk olahan bolu, cookies, dodol dan kerupuk yang disubstitusi tepung labu kuning dapat dilihat pada Gambar 5.
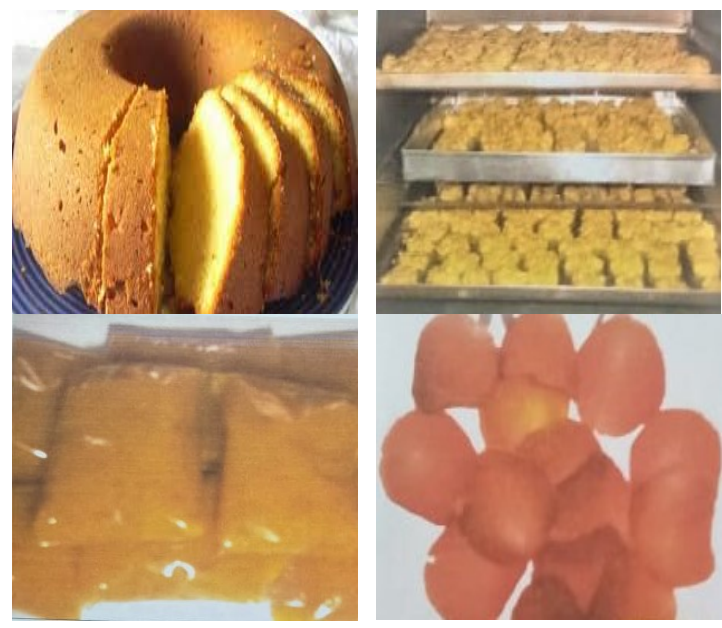

Gambar 5. Produk olahan tepung labu kuning; bolu/ cake, cookies, dodol dan kerupuk

Produk olahan pangan berbasis labu kuning yang dihasilkan pada kegiatan ini memiliki penampilan yang cukup menarik, dengan warna kuning muda sampai kuning tua dan rasa yang enak. Hal ini diharapkan dapat mendorong para peserta untuk mengembangkan produk olahan labu kuning ini menjadi satu usaha rumahan yang dapat menjadi sumber ekonomi bagi keluarga. Sebagai tahap awal, produk olahan labu kuning ini akan diikutkan dalam pameran pembangunan di tingkat provinsi sebagai upaya untuk mengenalkan produk ke masyarakat yang lebih luas. Pada akhir acara pelatihan diserahkan seperangkat alat untuk penepungan dan pembuatan produk olahan sebagai modal awal bagi warga untuk mengembangkan produk olahan labu kuning di kecamatan Daha Selatan.

Berdasarkan hasil wawancara kepada para peserta diketahui bahwa pada umumnya peserta cukup puas dengan kegiatan penyuluhan dan pelatihan pengolahan labu kuning, karena kegiatan ini menambah pengetahuan dan ketrampilan peserta tentang manfaat dan pengolahan labu kuning.

\section{SIMPULAN DAN SARAN Simpulan}

Pengolahan labu kuning menjadi berbagai produk olahana pangan merupakan salah satu alternatif untuk meningkatkan nilai tambah dan penganekaragaman pangan lokal yang selama ini masih terbatas. Pelaksanaan kegiatan ini berjalan lancar dan sukses. Peserta pelatihan mendapatkan ilmu pengetahuan dan ketrampilan baru dalam memanfaatkan dan mengolah labu kuning menjadi berbagai produk olahan pangan, yang selanjutnya dapat dikembangkan menjadi salah satu sumber ekonomi bagi warga masyarakat di kecamatan Daha Selatan.

\section{Saran}

Adapun Saran dari Kegiatan ini adalah masyarakat membutuhkan pendampingan secara kontinyu dalam pengolahan labu kuning menjadi berbagai produk olahan pangan, perlu dilakukan pelatihan mengenai disain dan pengemasan produk olahan pangan agar produk yang dihasilkan dapat dipasarkan menarik minat pembeli.

\section{UCAPAN TERIMA KASIH}

Terima kasih kami sampaikan kepada Pemerintah Daerah Kabupaten Hulu Sungai Selatan yang telah memberi dana kegiatan, Camat Daha Selatan, Pembakal dan seluruh masyarakat yang telah mendukung terlaksananya kegiatan ini.

\section{DAFTAR RUJUKAN}

Adams, G. G., Imran, S., Wang, S., Mohammad, A., Kok, S., Gray, D. A., Channell, G. A., Morris, G. A., \& Harding, S. E. (2011). The hypoglycaemic effect of pumpkins as anti-diabetic and functional medicines. Food Research International, 44(4), 862-867.

Carvalho, L. M. J., Patrícia, G., Godoy, R. L. D. O., Pacheco, S., Henrique, P., Luiz, J., 
Carvalho, V. De, Regini, M., Cristina, A., Neves, L., Carolina, A., Alves, R., Rabelo, S., \& Ramos, R. (2012). Total carotenoid content, $\alpha$-carotene and $\beta$ carotene, of landrace pumpkins (Cucurbita moschata Duch): A preliminary study. FRIN, 47(2), 337340.

Hassan, Z. H. (2014). Aneka Tepung Berbasis Bahan Baku Lokal Sebagai Sumber Pangan Fungsional Dalam Upaya Meningkatkan Nilai Tambah Produk Pangan Lokal. PANGAN, 23(1), 93107.

Millati, T., Udiantoro, \& Wahdah, R. (2006). Pemanfaatan Tepung Gumbili Nagara, Waluh dan Kacang Nagara sebagai Bahan Baku Industri Pengolahan Pangan. Laporan Penelitian. Fakultas Pertanian Universitas Lambung Mangkurat. Banjarbaru.

Reza, U., Putra, B. S., \& Nurba, D. (2019). Pengaruh Lama Perendaman Dalam Larutan Natrium Metabisulfit Terhadap Karakteristik Tepung Labu Kuning. Jurnal IImiah Mahasiswa Pertanian, 4(3), 115-124.

Safriani, N., El Husna, N., \& Rizkya, R. (2015). Pemanfaatan Pasta Labu Kuning (Cucurbita moschata) Pada Pembuatan Mi Kering. Jurnal Agroindustri, 5(2), 85-94.

Saroinsong, R. M., Mandey, L., \& Lalujan, L. (2015). Pengaruh Penambahan Labu Kuning (Cucurbita moschata) Terhadap Kualitas Fisikokimia Dodol. https://ejournal.unsrat.ac.id/index.php/ cocos/article/view/8815/8376.

Trisnawati, W., Suter, K., Suastika, K., \& Putra, N. K. (2014). Pengaruh Metode Pengeringan Terhadap Kandungan Antioksidan , Serat Pangan dan Komposisi Gizi Tepung Labu Kuning. Jurnal Aplikasi Teknologi Pangan, 3(4), 135-140.

Wulandari, Asyik, N., Sadimantara, \& M.Syukri. (2019). Pengaruh Penambahan Tepung Labu Kuning (Cucurbita Moschata L) Terhadap Uji Organoleptik dan Nlai Gizi Brownies Kukus Sebagai Makanan Selingan Tinggi BetaKaroten. J. Sains Dan Teknologi Pangan, 04(3), 2188-2203. 